\title{
Enhanced-Efficiency Phosphorous Fertilizer Impacts on Corn and Common Bean Crops and Soil Phosphorus Diffusion
}

\author{
Carlos Henrique Eiterer de Souza ${ }^{1}$, Roberto dos A. Reis $\mathrm{Jr}^{2}$, Victor Gustavo Soares Ribeiro ${ }^{1}$, \\ Murilo Mendes Machado ${ }^{1}$, Miguel Martins Neto ${ }^{1} \&$ Paulo Henrique Soares ${ }^{1}$ \\ ${ }^{1}$ University Center of Patos de Minas, Patos de Minas, MG, Brazil \\ ${ }^{2}$ Wirstchat Polímeros do Brasil, Londrina, PR, Brazil \\ Correspondence: Carlos Henrique Eiterer de Souza, University Center of Patos de Minas (UNIPAM), Patos de \\ Minas, MG, Brazil. E-mail: carloshenrique@unipam.edu.br
}

Received: May 11, 2020

doi:10.5539/jas.v12n7p15
Accepted: June 7, $2020 \quad$ Online Published: June 15, 2020

URL: https://doi.org/10.5539/jas.v12n7p15

\begin{abstract}
Phosphorus (P) supply to crops is a major constraint on the quantity and quality of food production in tropical soils, which are often characterized by highly weathered soils having low phosphorus use efficiency. Increasing $\mathrm{P}$ fertilizer use efficiency is a good tool for increasing food production to feed an increasing world population. Enhanced efficiency P fertilizer is used to achieve this goal. The lack of information about soil P diffusive flux and corn and common bean yield response with increased efficiency P fertilizers justify studies to evaluate the performance of this type of fertilizer. The aims of this study were to evaluate P diffusive flux and corn and common bean crop response to $\mathrm{P}$ sources and rates. A laboratory trial was carried out to evaluate soil $\mathrm{P}$ diffusive flux in response to P sources (MAP and Policote coated MAP). Field trials were carried out to evaluate corn and common bean yields in response to P sources (MAP and Policote coated MAP) and rates. Policote, an additive based on water-soluble polymers, is an anionic copolymer with iron an aluminum affinity. Increasing contact time between P-fertilizers and soil reduced phosphorus diffusive flux. Policote coated P-fertilizer resulted in higher phosphorus diffusion than conventional phosphorus fertilizer. Phosphorus fertilization increased corn and common bean yields. Policote coated phosphorus fertilizer resulted in higher agronomic P efficiency use, corn, and common bean yields than conventional phosphorus fertilizer. Policote coated P fertilizer can be used as an enhanced efficiency fertilizer and is a more efficient way to deliver required phosphorous to plants. Reducing farm investment, increasing agricultural profits, preserve phosphatic rocks reserves, and avoid the overuse of phosphate fertilizer could be realized through the rational use of enhanced efficiency fertilizers and fertilizer rate use reduction.
\end{abstract}

Keywords: agronomic efficiency, Policote, fertilizer technology developing

\section{Introduction}

Sub-optimal P nutrition can lead to crop yield losses in the range of $10 \%$ to $15 \%$ of the maximal yields (Shenoy $\&$ Kalagudi, 2005). Tropical regions are often characterized by highly weathered soils having low P stocks (Roy et al., 2016), high capacity for P sorption (Vitousek et al., 2010; Roy et al., 2016) and irreversible P fixation, favored by high contents of (hydr)oxides of Fe and Al (Abdala et al., 2015; Novais \& Smyth, 1999). These regions are widely expected to play a growing role in the world population feed. Amelioration attempts by the addition of P-fertilizers are economically and ecologically unsound as the efficiency of added P-fertilizers is very low (Shenoy \& Kalagudi, 2005). This scenario increases the pressure to increase P use efficiency. Currently, most commercial $\mathrm{P}$ fertilizers are water-soluble and $\mathrm{P}$ sorbs rapidly onto soil minerals, causing low $\mathrm{P}$ use efficiency and low residual values of these fertilizations (Everaert et al., 2017). The low efficiency of $P$ fertilization has been reported (Dorahy et al., 2008; Takahashi \& Anwar, 2007; Sanders et al., 2012; Dhillon et al., 2017; Dhillon et al., 2019). It is estimated that the plants absorb only 15 to $25 \%$ of P applied via fertilizer (Zanão et al., 2020). For this reason, much of the input $\mathrm{P}$ fertilizer is not used by crops. These $\mathrm{P}$ chemisorption processes greatly reduce the rate of $\mathrm{P}$ diffusion through the soil matrix to the root surface (Santner et al., 2015). Diffusion is considered the main mechanism for $\mathrm{P}$ transport in soils and is affected by a number of soil and solute parameters (Villani et al., 1998). P-fertilizer diffusion in the soil affects applied P efficiency by influencing the probability of root/P-fertilizer contact as well as soil/P-fertilizer contact (Eghball et al., 1990). 
The high $\mathrm{P}$ adsorption capacity of Al- and Fe-oxydroxydes in strongly weathered soils helps to maintain low levels of available phosphate (Johnson \& Loeppert, 2006; DeLong et al., 2013; Fink et al., 2014) and reduces its diffusive flux to the soil solution, thereby hindering or delaying approach of this anion to plant roots (Raghothama \& Karthikeyan, 2005).

Corn is the second-largest crop in Brazil's agricultural production, being surpassed only by the soybean crop that leads the grain production in the country. Common bean (Phaseolus vulgaris L.) is a food-secure and nutritious crop, playing a big dietary role, as supplying proteins, carbohydrates, essential elements and vitamins to both rural and urban households (Margaret et al., 2014). Brazilian producing areas are concentrated in the tropical regions, whose soils are highly weathered with low plant available phosphate. It is estimated that the world population will increase by $33 \%$ until 2050, from the current 7.2 billion to 9.6 billion people (Nalley et al., 2017) To provide adequate food, fiber, and renewable energy resources to meet this growth in population, we will need to dramatically increase crop yields (Heiniger et al., 2014), requiring, among several strategies, increasing the use of plant nutrients such as $\mathrm{P}$ applied in the form of fertilizers.

Developing new technologies to reduce $\mathrm{P}$ losses and increase its effectiveness is necessary to improve $\mathrm{P}$ management in tropical soils. For decades now, scientists and engineers have been working to understand what makes an agricultural system P efficient (Weeks Jr. \& Hettiarachchi, 2019) and several strategies have been used to increase $P$ fertilization efficiency (Zanão et al., 2020). There are a number of potential options to improve $P$ fertilizer use efficiency by plants (McLaughlin et al., 2011; Withers et al., 2014). One approach being heavily explored to improve $\mathrm{P}$ use efficiency is to limit the association of this nutrient with reactive components of the soil (Weeks Jr. \& Hettiarachchi, 2019) by using increased efficiency fertilizers. These fertilizers contain aggregate technologies that control the release of nutrients or stabilize their chemical transformations in the soil, increasing their availability to the plant (Pelá et al., 2019). This type of technology has long been used in nitrogen $(\mathrm{N})$ fertilizers, but its use in P fertilizers is small (Zanão et al., 2020). One of the used strategies in enhanced efficiency fertilizers is the addition of additives capable of inhibiting the transformation of nitrogen into the soil in some undesirable way (AAPFCO, 1997). A similar strategy could be applied with additives of iron and aluminum affinity, elements responsible for $\mathrm{P}$ fixation in the soil because it's possible to increase fertilizer agronomic efficiency by using these additives to cover it. Increasing $\mathrm{P}$ fertilizer efficiency with $\mathrm{P}$ fertilizer coated with anionic polymers (Policote) was demonstrated P by Reis Jr and Silva (2012), Chagas et al. (2015), Chagas et al. (2016), Chagas et al. (2017), Guelfi et al. (2018), Pelá et al. (2018), Pelá et al. (2019), and Zanão et al. (2020).

The lack of information about soil $\mathrm{P}$ diffusive flux and corn and common bean yield response with increased efficiency P fertilizers justify studies to evaluate the performance of this type of fertilizer. The aims of this study were to evaluate $\mathrm{P}$ diffusive flux and corn and common bean crop response to $\mathrm{P}$ sources and rates.

\section{Material and Methods}

Experiments were carried out to evaluate soil P diffusive flux and corn crop response to P sources (MAP and Policote coated MAP). Policote, an additive based on water-soluble anionic copolymers marketed by Wirstchat Polímeros do Brasil, with iron an aluminum affinity.

\subsection{Soil P Diffusive Flux}

A trial was carried out in Unipam Laboratory (Patos de Minas, MG, Brazil). The experiment was laid out in a Yellow-Red Oxisol, whose soil chemical and physical properties were $\mathrm{pH}\left(\mathrm{H}_{2} \mathrm{O}\right)=5.59$; organic matter $=2.0 \mathrm{~g}$ $\mathrm{dm}^{-3} ;$ Prem $=7.62 \mathrm{mg} \mathrm{L}^{-3} ; \mathrm{P}-\mathrm{Mehl}=0,22 \mathrm{mg} \mathrm{dm}$ - $; \mathrm{K}=54.9 \mathrm{mg} \mathrm{dm}{ }^{-3} ; \mathrm{Ca}=13 \mathrm{mmol}_{\mathrm{c}} \mathrm{dm}^{-3} ; \mathrm{Mg}=13.0 \mathrm{mmol}_{\mathrm{c}}$ $\mathrm{dm}^{-3} ; \mathrm{Al}=1.2 \mathrm{mmol}_{\mathrm{c}} \mathrm{dm}^{-3} ; \mathrm{H}+\mathrm{Al}=27 \mathrm{mmol}_{\mathrm{c}} \mathrm{dm}^{-3} ; \mathrm{CEC}=54.4 \mathrm{mmol}_{\mathrm{c}} \mathrm{dm}^{-3} ;$ base saturation $=50 \%$; clay $=650$ $\mathrm{g} \mathrm{kg}^{-1}$. The treatments were arranged entirely at random with four replicates, in a factorial $(3 \times 9)$, using two $\mathrm{P}$ sources [Control; MAP $\left(11 \% \mathrm{~N}, 52 \% \mathrm{P}_{2} \mathrm{O}_{5}\right)$ and Policote coated MAP $\left(10 \% \mathrm{~N}, 49 \% \mathrm{P}_{2} \mathrm{O}_{5}\right)$ ] and nine incubation times $(3 ; 6 ; 9 ; 12 ; 18 ; 24 ; 36 ; 48$ and 60 days). The experimental unit was formed by a Ger-box chamber with a capacity of $0.3 \mathrm{dm}^{3}$ of soil. The experimental plots were filled to half of their volume with the soil, followed by the application of fertilizers at rate of $1,000 \mathrm{mg} \mathrm{dm}^{-3} \mathrm{P}$ (corresponding to the maximum capacity of adsorption of $\mathrm{P}$ in the soil), except for Control, in the center of the experimental plot. Subsequently, a $0.5 \mathrm{~cm}$ layer of soil was deposited and anion exchange resin sheets (AER; $2 \times 2 \mathrm{~cm}$ ) were installed over, followed by the application of the rest of the soil until the plot capacity experimental. After the application of P sources, the soil moisture was maintained at $80 \%$ of the field capacity. After each incubation time, the AERs were removed from the experimental plot and washed with water (to remove adhered soil) and dried on filter paper. Subsequently, P was extracted from the AERs with a solution of $\mathrm{NH}_{4} \mathrm{Cl} 0.8 \mathrm{~mol} \mathrm{~L}^{-1}$ and $\mathrm{HCl} 0.2 \mathrm{~mol} \mathrm{~L}^{-1}$, after stirring at $200 \mathrm{rpm}$ for one hour, according to the methodology described by Raij et al. (1987), and determination of the P content 
(Braga \& Defelipo, 1974). The phosphorus diffusive flux (PDF) in the soil has been directly estimated by the use of AER (Amer et al., 1995) and by the use of filter paper impregnated with iron and aluminum oxides (Van der Zee et al., 1987; Menon et al., 1989), also called anionic paper. The AER adsorb the P from the soil solution, in its vicinity, similar to the behavior of a root, creating a gradient of concentration of $\mathrm{P}$ as it moves away from the AER. It is an indirect measure of PDF because it determines the P that reaches a known surface of AER, as it could be from a root, for a given period. Thus, the estimation of the diffusive flow, for each incubation time, was performed by quantifying the P adsorbed to the AER. With observed PDF after each incubation time (amount accumulated in the incubation period), the daily diffusive flow of phosphorus (DDFP) in the subsequent incubation time was calculated, according to the equation below, and the accumulated PDF was calculated.

$$
\mathrm{DDFP}=\frac{\mathrm{PDF}_{\text {final }}-\mathrm{FDF}_{\text {initial }}}{\text { Time }(\text { days })}
$$

\subsection{Corn Crop}

A corn trial was carried out in Lagoa Formosa, MG, Brazil $\left(18^{\circ} 30^{\prime} 58.4^{\prime \prime} \mathrm{S}, 46^{\circ} 12^{\prime} 34.6^{\prime \prime} \mathrm{W}\right.$ and average altitude around $886 \mathrm{~m}$ ), whose climate is classified as Aw, with average temperature of $22.2^{\circ} \mathrm{C}$ and average precipitation of $1462 \mathrm{~mm}$. The experiment was laid out in a Yellow-Red Oxisol, whose 0-0.2 m layer soil chemical and physical properties were $\mathrm{pH}\left(\mathrm{H}_{2} \mathrm{O}\right)=6.41 ;$ organic matter $=30.0 \mathrm{~g} \mathrm{dm}^{-3} ;$ Prem $=4.93 \mathrm{mg} \mathrm{L}^{-3} ; \mathrm{P}-\mathrm{Mehl}=0.26 \mathrm{mg}$ $\mathrm{dm}^{-3} ; \mathrm{K}=50.7 \mathrm{mg} \mathrm{dm}{ }^{-3} ; \mathrm{Ca}=18 \mathrm{mmol}_{\mathrm{c}} \mathrm{dm}^{-3} ; \mathrm{Mg}=8.0 \mathrm{mmol}_{\mathrm{c}} \mathrm{dm}^{-3} ; \mathrm{Al}=0.1 \mathrm{mmol}_{\mathrm{c}} \mathrm{dm}^{-3} ; \mathrm{H}+\mathrm{Al}=33 \mathrm{mmol}_{\mathrm{c}}$ $\mathrm{dm}^{-3} ; \mathrm{CEC}=60.3 \mathrm{mmol}_{\mathrm{c}} \mathrm{dm}^{-3}$; base saturation $=45 \%$; clay $=550 \mathrm{~g} \mathrm{~kg}^{-1}$. The soil $\mathrm{P}$ availability is classified as "Very Low" (CFSEMG, 1999).

The treatments, applied in the planting furrow, were arranged in an incomplete factorial $(2 \times 4)+1$, using two $\mathrm{P}$ sources (MAP and Policote coated MAP), four P rates $\left(40,80,120\right.$ and $160 \mathrm{~kg} \mathrm{ha}^{-1} \mathrm{P}_{2} \mathrm{O}_{5}$ ) and control (without $\mathrm{P}$ application). A complete block design, with four replication, was used. Each experimental plot had five rows, spaced $0.5 \mathrm{~m}$, and seven meters long. The SHS7990 Pro cultivar was sown, after nitrogen (total $40 \mathrm{~kg} \mathrm{ha}^{-1} \mathrm{~N}$; urea), potassium $\left(50 \mathrm{~kg} \mathrm{ha}^{-1} \mathrm{~K}_{2} \mathrm{O} ; \mathrm{KCl}\right)$ and treatments applications in the sowing furrow, at December, $8^{\text {th }}, 2017$. Nitrogen and potassium $\left(70 \mathrm{~kg} \mathrm{~N}+70 \mathrm{~kg} \mathrm{~K}_{2} \mathrm{O} \mathrm{ha}^{-1}\right.$ on $\mathrm{V} 4$ stage and $50 \mathrm{~kg} \mathrm{ha}^{-1} \mathrm{~N}$ on V6 stage; urea and $\left.\mathrm{KCl}\right)$ were applied on top surface soil. Weed, pest and disease controls were made. The number of row/ear ratio, number of grain/row ratio and yield (corn spikes were manually cut, followed by manual threshing and moisture content correction to $13 \%$, humid base) were evaluated on the three central rows of the experimental plot at harvest (April 25, 2018).

\subsection{Common Bean Crop}

A common bean trial was carried out in Patos de Minas, MG, Brazil $\left(18^{\circ} 42^{\prime} 45.2^{\prime \prime} \mathrm{S}, 46^{\circ} 31^{\prime} 51.5^{\prime \prime} \mathrm{W}\right.$ and average altitude around $840 \mathrm{~m}$ ), whose climate is classified as Aw, with average temperature of $22.8^{\circ} \mathrm{C}$ and average precipitation of $1445 \mathrm{~mm}$ The experiment was laid out in a Yellow Oxisol, whose 0-0.2 m layer soil chemical and physical properties were $\mathrm{pH}\left(\mathrm{H}_{2} \mathrm{O}\right)=6.09$; organic matter $=20.7 \mathrm{~g} \mathrm{dm}^{-3} ;$ Prem $=3.43 \mathrm{mg} \mathrm{L}^{-3} ; \mathrm{P}-\mathrm{Mehl}=6.22$ $\mathrm{mg} \mathrm{dm}{ }^{-3} ; \mathrm{K}=1.00 \mathrm{mmol}_{\mathrm{c}} \mathrm{dm}^{-3} ; \mathrm{Ca}=27 \mathrm{mmol}_{\mathrm{c}} \mathrm{dm}^{-3} ; \mathrm{Mg}=9.0 \mathrm{mmol}_{\mathrm{c}} \mathrm{dm}^{-3} ; \mathrm{Al}=1.0 \mathrm{mmol}_{\mathrm{c}} \mathrm{dm}^{-3} ; \mathrm{H}+\mathrm{Al}=44$ mmol $_{\mathrm{c}} \mathrm{dm}^{-3} ; \mathrm{CEC}=81.0 \mathrm{mmol}_{\mathrm{c}} \mathrm{dm}^{-3}$; base saturation $=45.7 \%$. The soil $\mathrm{P}$ availability is classified as "Good" (CFSEMG, 1999).

The treatments, applied in the planting furrow, were arranged in an incomplete factorial $(2 \times 4)+1$, using two $\mathrm{P}$ sources (MAP and Policote coated MAP), four P rates $\left(25,50,75\right.$ and $100 \mathrm{~kg} \mathrm{ha}^{-1} \mathrm{P}_{2} \mathrm{O}_{5}$ ) and control (without P application). A complete block design, with four replication, was used. Each experimental plot had five rows, spaced $0.5 \mathrm{~m}$, and ten meters long. The Pérola cultivar was sown, after nitrogen (total $20 \mathrm{~kg} \mathrm{~N} \mathrm{ha}^{-1}$; urea), potassium $\left(30 \mathrm{~kg} \mathrm{ha}^{-1} \mathrm{~K}_{2} \mathrm{O} ; \mathrm{KCl}\right)$ and treatments applications in the sowing furrow, at April 20, 2018. Nitrogen $\left(45 \mathrm{~kg} \mathrm{ha}^{-1} \mathrm{~N}\right.$; urea) and potassium $\left(30 \mathrm{~kg} \mathrm{ha}^{-1} \mathrm{~K}_{2} \mathrm{O}\right.$ ) were applied on top surface soil at 25 days after plant emergence. Weed, pest and disease controls were made. Common bean yield was evaluated (bean pod was manually cut, followed by manual threshing and moisture content correction to $13 \%$, humid base) on the three central rows of the experimental plot at harvest (April 25, 2018).

\subsection{Statistical Analyses}

Statistical analyses were performed with the statistical software package R (R core Team, 2016). An analysis of variance was run to test the significance of the $\mathrm{P}$ fertilizers and incubation time. The Shapiro-Wilk test was performed to test the residuals for normal distribution. Multiple comparisons were made using the Tukey's Test $(\mathrm{P}<0.05)$. The phosphorus agronomic efficiency index (Fageria et al., 2010) was calculated with average corn and common bean yields. 


\section{Results and Discusion}

\subsection{Soil P Diffusive Flux}

Figure 1 shows the time course of $\mathrm{P}$ diffusion to the AER. The phosphorus diffusive flux (PDF) was significantly influenced by the phosphorus sources $(p<0.01)$ and incubation times $(p<0.01)$, with significant interaction between $P$ sources and incubation times $(p<0.01)$. In evaluations performed up to 36 days of incubation, the PDFs observed with MAP and Policote coated MAP were equal to each other and superior to the Control (Figure 1). In the evaluations carried out at 48 and 60 days of incubation, the PDF was statistically different between the P sources, when the Policoted coated MAP presented the highest PDF levels. The accumulated PDF increased with time, but stabilized with 24 days of MAP incubation, while it continued to increase with Policote coated MAP. Accumulated P diffusive flux with Policote coated MAP was $23.1 \%$ higher than with MAP, after 60 incubation days. Understanding the processes that influence the diffusive flow of $\mathrm{P}$ from fertilizer granules, especially when placed away from seeds, is important to increase its availability for plants in tropical soils.

Diffusion is the main mechanism for transporting phosphorus in the soil, which is influenced by several factors, such as the volumetric water content in the soil, the phosphorus-colloid interaction of the soil, the distance to reach the roots, the element content and soil temperature (Costa et al., 2006). The volumetric water content in the soil, the distance from fertilizer to AER (to reach the roots), the fertilizer supply (element content) and the soil temperature were the same among treatments (fertilizer source and incubation time) in this experiment. So, differences in phosphorus-colloid interaction of the soil explains the different $\mathrm{P}$ diffusive flux from different fertilizer source and incubation time. A reduction in $\mathrm{P}$ adsorption capacity of iron and aluminum oxides and hydroxides increases $\mathrm{P}$ diffusive flux and benefit crop P nutrition. The effect of fertilizer source and incubation time on P diffusive flux has been studied. P diffusive flux reductions with increasing incubation time were reported by Villani et al., (1988), explanining plant growth and soil available $\mathrm{P}$ reductions with increasing incubation time, as reported by Gonçalves et al. (1989). Different $\mathrm{P}$ sources $\left[\mathrm{Ca}\left(\mathrm{H}_{2} \mathrm{PO}_{4}\right)_{2}, \mathrm{NH}_{4} \mathrm{H}_{2} \mathrm{PO}_{4},\left(\mathrm{NH}_{4}\right)_{2} \mathrm{HPO}_{4}, \mathrm{Na}_{2} \mathrm{HPO}_{4} \cdot 2 \mathrm{H}_{2} \mathrm{O}\right.$, and $\left.\mathrm{K}_{2} \mathrm{HPO}_{4}\right]$ resulted in diferente P diffusive flux (Villani et al., 1988). Policote coated fertilizer increased P diffusive flux.

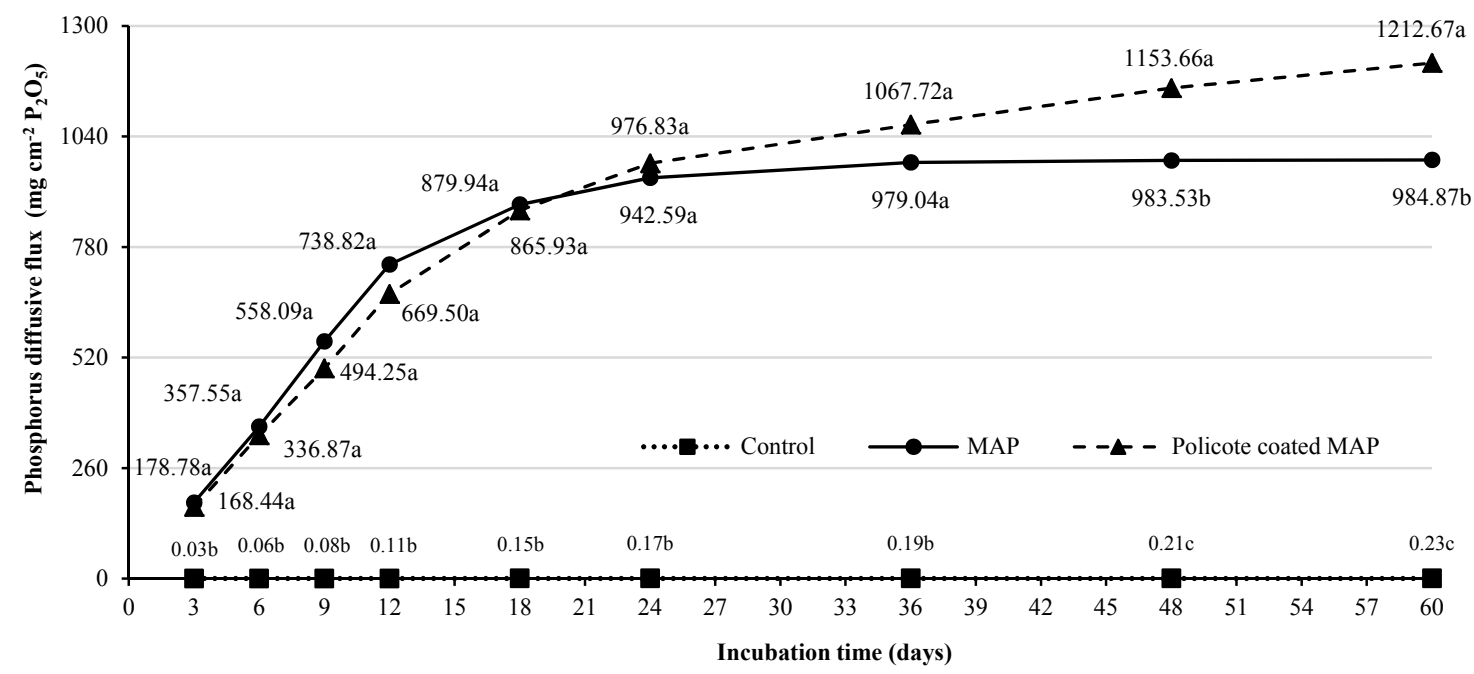

Figure 1. Accumulated phosphorus diffusive flux in response to $P$ sources and incubation time. Means followed by the same letter in the same incubation time do not differ statistically among themselves by Tukey test $(p<0.05)$

\subsection{Corn Crop}

Fertilization increased the number of row/ear (NRE; Figure 2), the number of grain/row (NGR; Figure 3) and corn yield (Figure 4). NRE increased from 11.3 (without $\mathrm{P}$ fertilization) up to $14.1\left(145.1 \mathrm{~kg} \mathrm{ha}^{-1} \mathrm{P}_{2} \mathrm{O}_{5}\right.$, with MAP) and 17.3 (117.2 $\mathrm{kg} \mathrm{P}_{2} \mathrm{O}_{5} \mathrm{ha}^{-1}$, with Policote coated MAP). NGR increased from 21.1 (without $\mathrm{P}$ fertilization) up to $35.2\left(134.2 \mathrm{~kg} \mathrm{ha}^{-1} \mathrm{P}_{2} \mathrm{O}_{5}\right.$, with MAP) and $37.0\left(116.1 \mathrm{~kg} \mathrm{ha}^{-1} \mathrm{P}_{2} \mathrm{O}_{5}\right.$, with Policote coated MAP). Increasing NRE with P fertilization was also reported by Soares et al. (2018).

The corn yield increased from 4,515.9 $\mathrm{kg} \mathrm{ha}^{-1}$ (without $\mathrm{P}$ fertilization) up to 9,038.4 $\mathrm{kg} \mathrm{ha}^{-1}\left(160 \mathrm{~kg} \mathrm{ha}^{-1} \mathrm{P}_{2} \mathrm{O}_{5}\right.$, with MAP) and 9,562.3 $\mathrm{kg} \mathrm{ha}^{-1}\left(118.7 \mathrm{~kg} \mathrm{ha}^{-1} \mathrm{P}_{2} \mathrm{O}_{5}\right.$, with Policote coated MAP). Higher crop yields with $\mathrm{P}$ 
enhanced fertilizer were also reported by Sanders et al. (2012) and Noor et al. (2018). Higher corn yields with Policote coated P fertilizer were also reported by Pela et al. (2019) and Zanão et al. (2020). Coating of phosphatic fertilizers with the polymer is an innovative option to improve phosphorus use efficiency (Noor et al., 2017).

Phosphorus rate recommendation, considering soil $\mathrm{P}$ content availability, to corn crop is $120 \mathrm{~kg} \mathrm{ha}^{-1} \mathrm{P}_{2} \mathrm{O}_{5}$ (CFSEMG, 1999). Corn yield with $120 \mathrm{~kg} \mathrm{ha}^{-1} \mathrm{P}_{2} \mathrm{O}_{5}$ and MAP was $8,628.3 \mathrm{~kg} \mathrm{ha}^{-1}$, while using the same P rate and Policote coated MAP it was $9,561.7 \mathrm{~kg} \mathrm{ha}^{-1}$, an increase of $10.8 \%$. The corn yield obtained with the recommended $\mathrm{P}$ rate based on soil analisys $\left(120 \mathrm{~kg} \mathrm{ha}^{-1} \mathrm{P}_{2} \mathrm{O}_{5}\right.$ and MAP) was reached with $66.4 \mathrm{~kg} \mathrm{ha}^{-1} \mathrm{P}_{2} \mathrm{O}_{5}$ and Policote coated MAP.

\subsection{Common Bean Crop}

$\mathrm{P}$ fertilization increased common bean yield (Figure 5). Common bean yield increased from $1362.0 \mathrm{~kg} \mathrm{ha}^{-1}$ (without P fertilization) up to 2,952.2 kg.ha ${ }^{-1}$ (96.9 kg ha ${ }^{-1} \mathrm{P}_{2} \mathrm{O}_{5}$, with MAP) and 3,610.3 kg ha ${ }^{-1}$ (86.0 kg ha $\mathrm{P}_{2} \mathrm{O}_{5}$, with Policote coated MAP).

Phosphorus rate recommendation, considering soil $\mathrm{P}$ content availability, to common bean crop is $90 \mathrm{~kg} \mathrm{ha}^{-1}$ $\mathrm{P}_{2} \mathrm{O}_{5}$ (CFSEMG, 1999). Common bean yield with $90 \mathrm{~kg} \mathrm{ha}^{-1} \mathrm{P}_{2} \mathrm{O}_{5}$ and MAP was 2,947.7 kg ha ${ }^{-1}$, while using the same P rate and Policote coated MAP it was 3,605.4 kg.ha ${ }^{-1}$, an increase of $22.3 \%$. The common bean yield obtained with the recommended $\mathrm{P}$ rate based on soil analisys $\left(90 \mathrm{~kg} \mathrm{ha}^{-1} \mathrm{P}_{2} \mathrm{O}_{5}\right.$ and MAP) was reached with 39.3 $\mathrm{kg} \mathrm{ha}^{-1} \mathrm{P}_{2} \mathrm{O}_{5}$ and Policote coated MAP. Lower $\mathrm{P}$ rates using polymer coated $\mathrm{P}$ fertilizer than conventional $\mathrm{P}$ fertilizer were also reported by Ali et al. (2017) to achieve the same yield. Reduced P rate using allows reducing farm investment, increasing agricultural profits, preserve phosphatic rocks reserves, and avoid the overuse of phosphate fertilizer.

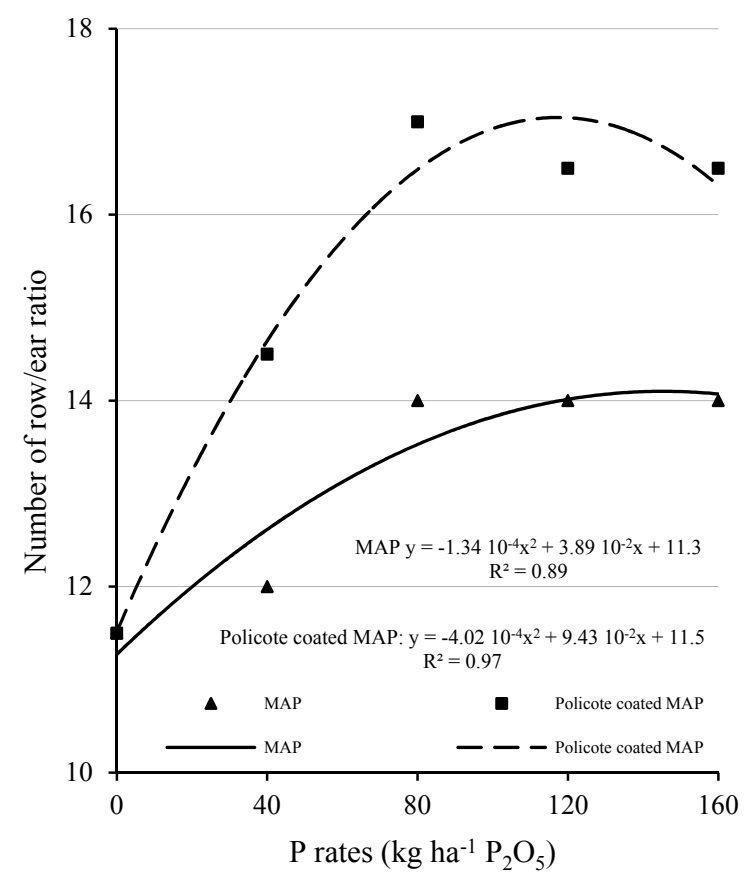

Figure 2. Number of row/ear ratio in response to $P$ sources and rates in corn crop

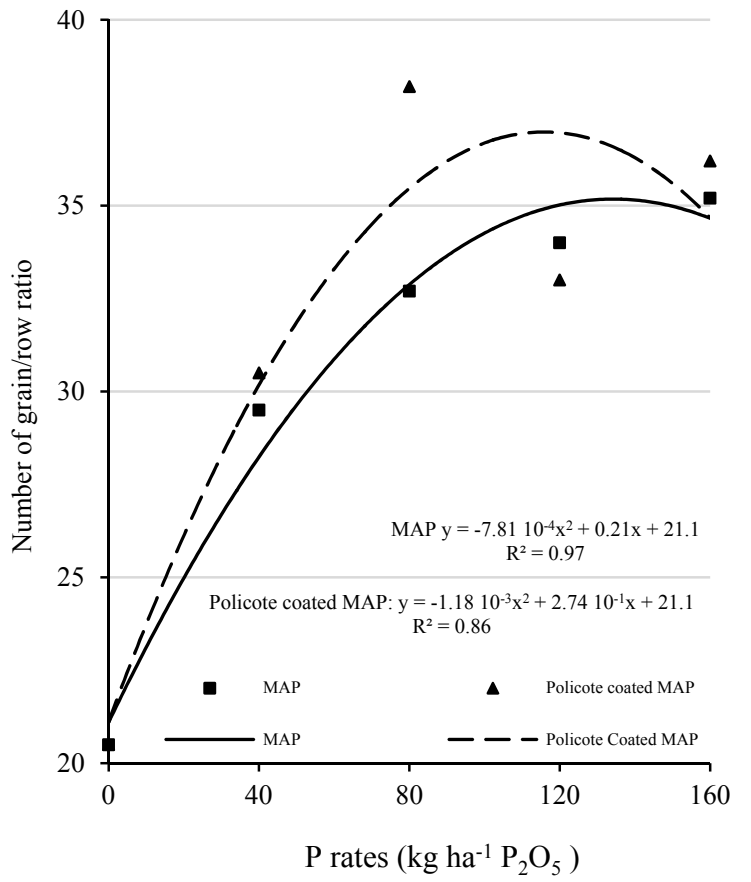

Figure 3. Number of grain/row ratio in response to $P$ sources and rates in corn crop 


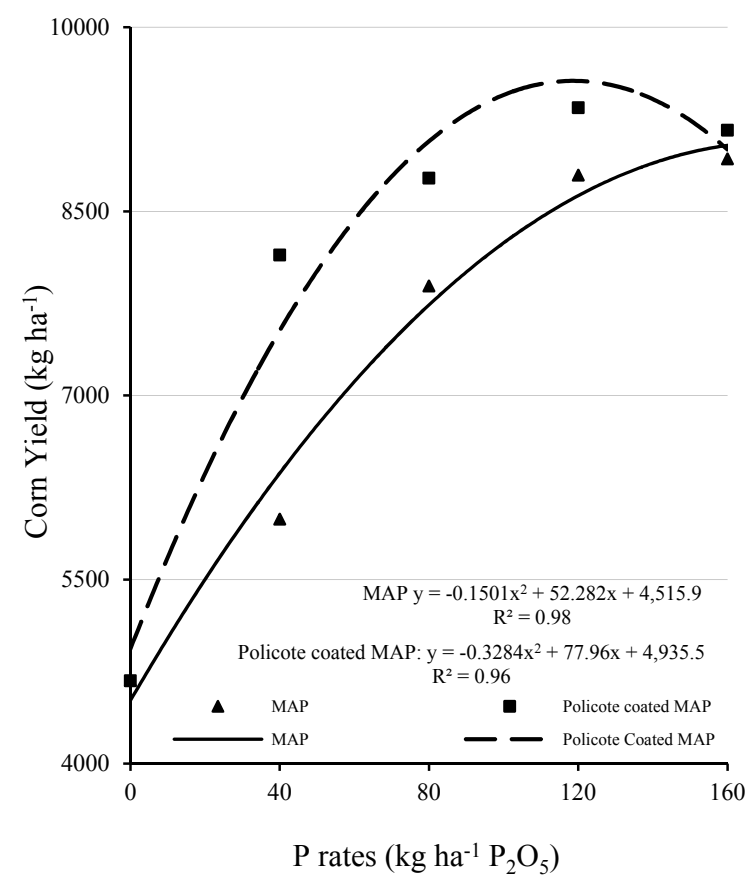

Figure 4. Corn yield in response to $P$ sources and rates

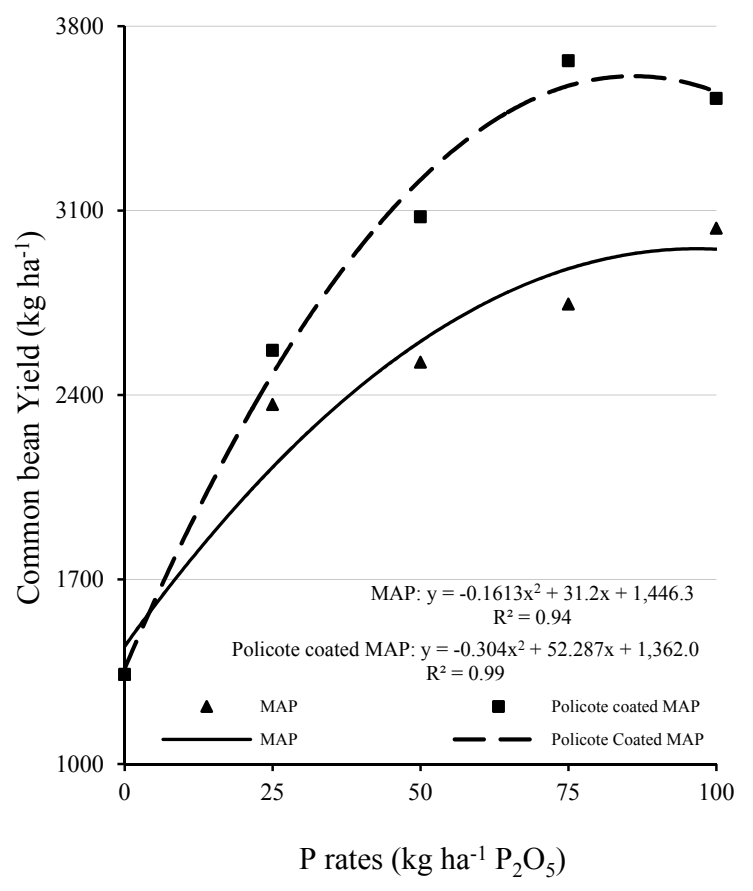

Figure 5. Common bean yield in response to $P$ sources and rates

\subsection{Agronomic P Use Efficiency}

Table 1 shows the agronomic phosphorus use efficiency (APUE) in response to P sources and rates. Increasing $\mathrm{P}$ rates decreased APEU. It is explained by Mitscherlich's law of diminishing returns because there is a decreasing marginal yield as levels of the limiting factor are raised. However, Policote coated fertilizer resulted in higher APEU than conventional fertilizer. The increase in corn ans common bean yields using Policote coated MAP was a consequence of the higher agronomic efficiency observed with this enhanced efficiency fertilizer. Policote coated P fertilizer is a more efficient way to deliver required phosphorous to plants. The same APEU trend was reported by Zanão et al. (2020), but with lower APUE than observed in this experiment.

Table 1. Agronomic phosphorus use index in response to $\mathrm{P}$ sources and rates

\begin{tabular}{|c|c|c|c|c|c|}
\hline \multirow{2}{*}{$P_{2} O_{5}\left(\mathrm{~kg} \mathrm{ha}^{-1}\right)$} & \multicolumn{2}{|c|}{$\begin{array}{c}\text { Corn Crop } \\
\left(\mathrm{kg} \text { corn } \mathrm{kg}^{-1} \mathrm{P}_{2} \mathrm{O}_{5}\right)\end{array}$} & \multirow[t]{2}{*}{$P_{2} O_{5}\left(\mathrm{~kg} \mathrm{ha}^{-1}\right)$} & \multicolumn{2}{|c|}{$\begin{array}{c}\text { Common Bean Crop } \\
\left(\mathrm{kg} \text { common bean } \mathrm{kg}^{-1} \mathrm{P}_{2} \mathrm{O}_{5}\right)\end{array}$} \\
\hline & MAP & Policote Coated MAP & & MAP & Policote Coated MAP \\
\hline 40 & 32.88 & 86.69 & 25 & 41.0 & 49.1 \\
\hline 80 & 40.02 & 51.18 & 50 & 23.7 & 34.7 \\
\hline 120 & 34.29 & 38.90 & 75 & 18.7 & 31.0 \\
\hline 160 & 26.57 & 28.03 & 100 & 16.9 & 21.8 \\
\hline Mean & 33.44 & 51.19 & & 25.0 & 34.1 \\
\hline
\end{tabular}

Increasing $\mathrm{P}$ difussive flux and agronomic P use efficiency explains increasing yields with Policote coated $\mathrm{P}$ fertilizer.

\section{Conclusions}

Incubation time (contact time between P fertilizers and soil) reduced phosphorus diffusive flux. Policote coated phosphorus fertilizer resulted in higher phosphorus diffusion than conventional phosphorus fertilizer.

Phosphorus fertilization increased corn and common bean yields. Policote coated phosphorus fertilizer resulted in higher agronomic P efficiency use, corn and common bean yields than conventional phosphorus fertilizer. 
Increasing $\mathrm{P}$ difusive flux and agronomic $\mathrm{P}$ use efficiency explains increasing yields with Policote coated $\mathrm{P}$ fertilizer.

Policote coated $\mathrm{P}$ fertilizer can be used as an enhanced efficiency fertilizer and is a more efficient way to deliver required phosphorous to plants. Reducing farm investment, increasing agricultural profits, preserve phosphatic rocks reserves, and avoid the overuse of phosphate fertilizer could be realized through the rational use of enhanced efficiency fertilizers and fertilizer rate use reduction.

\section{References}

AAPFCO (Association of American Plant Food Control Officials). (1997). Official documents 57. West Lafayette: AAPFCO.

Abdala, D. B., Northrup, P. A., Arai, Y., \& Sparks, D. L. (2015). Surface loading effects on or- thophosphate surface complexation at the goethite/water interface as examined by extended X-ray Absorption Fine Structure (EXAFS) spectroscopy. J. Colloid Interface Sci., 437, 297-303. https://doi.org/10.1016/ j.jcis.2014.09.057

Ali, I., Mustafa, A., Yassen, M., \& Imran, M. (2017). Polymer coated dap helps in enhancing growth, yield and phosphorus use efficiency of wheat (Triticum aestivum L.). Journal of Plant Nutrition, 40(18), $2587-2594$. https://doi.org/10.1080/01904167.2017.1381118

CFSEMG (Comissão de Fertilidade do Solo do Estado de Minas Gerais). (1999). Recomendações para o uso de corretivos e fertilizantes em Minas Gerais (5th ed., p. 310). Viçosa, MG.

Chagas, W. F. T., Emrich, E. B., Guelfi, D. R., Caputo, A. L. C., \& Faquin V. F. (2015). Productive characteristics, nutrition and agronomic efficiency of polymer-coated MAP in lettuce crops. Revista Ciência Agronômica, 46(2), 266-275. https://doi.org/10.5935/1806-6690.20150006

Chagas, W. F. T., Guelfi, D. R., Caputo, A. L. C., Dominghetti, A, W., Faquin, V. F., Lopes, R. M., \& Chagas, R. M. R. (2016). Eficiência agronômica do superfosfato triplo revestidos com polímeros no crescimento inicial do cafeeiro. Coffee Science, 11(3), 427-435.

Chagas, W. F. T., Guelfi, D. R., Emrich, E. B., Silveira, M. T. P., Caputo,A. L. C. C., Andrade, A. B., ... Soares, L. S. (2017). Agronomic characteristics of lettuce grown with monoammonium phosphate in sandy soil. Communications in Soil Science and Plant Analysis, 48(13), 1-8. https://doi.org/10.1080/0010362 4.2017.1373793

Costa, J. P. V., Barros N. F., Albuquerque, A. W., Moura, F., \& Santos, J. R. (2006). Fluxo difusivo de fósforo em função de doses e da umidade do solo. Revista Brasileira de Engenharia Agrícola e Ambiental, 10(40), 828-835. https://doi.org/10.1590/S1415-43662006000400007

DeLonge, M., Vandecar, K. L., D’Odorico, P., \& Lawrence, D. (2013). The impact of changing moisture conditions on short-term P availability in weathered soils. Plant and Soil, 365, 201-209. https://doi.org/ 10.1007/s11104-012-1373-6

Dhillon, J. S., Eickhoff, E. M., Mullen, R. W., \& Raun, W. R. (2019). World Potassium Use Efficiency in Cereal Crops. Agronomy Journal, 111(2), 1-8. https://doi.org/10.2134/agronj2018.07.0462

Dhillon, J., Torres, G., Driver, E., Figueiredo, B., \& Raun, W. R. (2017). World Phosphorus Use Efficiency in Cereal Crops. Agronomy Journal, 109(4), 1670-1677. https://doi.org/10.2134/agronj2016.08.0483

Dorahy, C. G., Rochester, I. J., Blair, G. J., \& Till, A. R. (2008). Phosphorus Use-Efficiency by Cotton Grown in an Alkaline Soil as Determined Using 32 Phosphorus and 33 Phosphorus Radio-Isotopes. Journal of Plant Nutrition, 31, 1877-1888. https://doi.org/10.1080/01904160802402716

Eghball, B., Sander, D. H., \& Skopp, J. (1990). Diffusion, Adsorption, and Predicted Longevity of Banded Phosphorus Fertilizer in Three Soils. Soil Science Society of America Journal, 54(4), 1161. https://doi.org/10.2136/sssaj1990.0361599500540004004

Everaert, M., Degryse, F., McLaughlin, M. J., De Vos, D., \& Smolders, E. (2017). Agronomic effectiveness of granulated and powdered P-exchanged Mg-Al LDH relative to struvite and MAP. J. Agric. Food Chem., 65, 6736-6744. https://doi.org/10.1021/acs.jafc.7b01031

Fink, J. R., Inda, A. V., Bavaresco, J., Sánchez-Rodríguez, A. R., Barrón, V., Torrent, J., \& Bayer, C. (2015). Diffusion and uptake of phosphorus, and root development of corn seedlings, in three contrasting subtropical soils under conventional tillage or no-tillage. Biology and Fertility of Soils, 52(2), 203-210. https://doi.org/10.1007/s00374-015-1067-3 
Gonçalves, J. L. M., Novais, R. F., Barros, N. F., Neves, J. C. L., \& Ribeiro, A. C. (1989). Cinética de transformação de P-lábil em não-lábil, em solos de cerrado. Revista Brasileira de Ciência do Solo, 13, $13-24$.

Guelfi, D. R., Chagas, W. F. T., Lacerda, J. R., Chagas, R. M. R., Souza, T. L., \& Andrade, A. B. (2018). Monoammonium phosphate coated with polymers and magnesium for coffee plants. Ciência $e$ Agrotecnologia, 42(3), 261-270. https://doi.org/10.1590/1413-70542018423002918

Johnson, S., \& Loeppert, R. H. (2006). Role of organic acids in phosphate mobilization from iron oxide. Soil Science Society American Journal, 70, 222-234. https://doi.org/10. 2136/sssaj2005.0012

Margaret, N., Tenywa, J. S., Otabbong, E., Mubiru, D. N., \& Basamba, T. A. (2014). Development of Common Bean (Phaseolus Vulgaris L.) Production Under Low Soil Phosphorus and Drought in Sub-Saharan Africa: A Review. Journal of Sustainable Development, 7(5), 128-139. https://doi.org/10.5539/jsd.v7n5p128

McLaughlin, M. J., McBeath, T. M., Smernik, R., Stacey, S. P., Ajiboye, B., \& Guppy, C. (2011). The chemical nature of $\mathrm{P}$ accumulation in agricultural soils-implications for fertiliser management and design: An Australian perspective. Plant and Soil, 349, 69-87. https://doi.org/10.1007/s11104-011-0907-7

Noor, S., Yaseen, M., Naveed, M., \& Ahmad, R. (2017). Use of controlled release phosphatic fertilizer to improve growth, yield and phosphorus use efficiency of wheat crop. Pak. J. Agri. Sci., 54(4), 541-547. https://doi.org/10.21162/PAKJAS/18.6533

Novais, R. F., \& Smyth, T. J. (1999). Fósforo em solo e planta em condições tropicais. Universidade Federal de Viçosa, Viçosa.

Pelá, A., Bento, R. U., Crispim, L. B. R., \& Reis Jr, R. A. (2019). Enhanced efficiency of phosphorus fertilizer in soybean and maize. Australian Journal of Crop Science, 13(10), 1638-1642. https://doi.org/10.21475/ ajcs.19.13.10.p1853

Pelá, A., Ribeiro, M. A., Bento, R. U., Cirino, L. H. B., \& Reis Jr, R. A. (2018). Enhanced-efficiency phosphorus fertilizer: Promising technology for carrot crop. Horticultura Brasileira, 36, 492-497. https://doi.org/ 10.1590/S0102-053620180411

R core Team. (2016). R: A Language and Environment for Statistical Computing.

Raghothama, K. G., \& Karthikeyan, A. S. (2005). Phosphate acquisition. Plant and Soil, 274, 37-49. https://doi.org/10.1007/s11104-004-2005-6

Reis Jr, R. A., \& Silva, D. R. G. (2012). Avaliação das características físicas e físico químicas de fertilizantes nitrogenados e fosfatados revestidos por polímeros. Magistra, 24, 145-150.

Roy, E. D., Richards, P. D., Martinelli, L. A., Coletta, L. D., Lins, S. R. M., Vazquez, F. F., ... Porder, S. (2016). The phosphorus cost of agricultural intensification in the tropics. Nat. Plants, 2, 16043. https://doi.org/10.1038/nplants.2016.43

Sanders, J. L., Murphy, L. S., Noblec, A., Melgard, R. J., \& Perkinsa, J. (2012). Improving Phosphorus use Efficiency with Polymer Technology. Procedia Engineering, 46, 178-184. https://doi.org/10.1016/j.proeng. 2012.09.463

Santner, J., Mannel, M., Burrell, L. D., Hoefer, C., Kreuzeder, A., \& Wenzel, W. W. (2015). Phosphorus uptake by Zea mays L. is quantitatively predicted by infinite sink extraction of soil P. Plant and Soil, 386, 371-383. https://doi.org/10.1007/s11104-014-2271-x

Shenoy, V. V., \& Kalagudi, G. M. (2005). Enhancing plant phosphorus use efficiency for sustainable cropping. Biotechnol. Adv., 23, 501-513. https://doi.org/10.1016/j.biotechadv.2005.01.004

Soares, G. F., Cruz, S. C. S., Duarte, T. C., Machado, C. G., \& Sena Jr, D. G. (2018). Gypsum and phosphorus in improving biometric and nutritional attributes of soybean/second season corn succession. Rev. Caatinga, 31(2), 326-335. https://doi.org/10.1590/1983-21252018v31n208rc

Takahashi, S., \& Anwar, M. R. (2007). Wheat grain yield, phosphorus uptake and soil phosphorus fraction after 23 years of annual fertilizer application to an Andosol. Field Crop Res., 101, 160-171. https://doi.org/ 10.1016/j.fcr.2006.11.003

Villani, E. M. A., Barros, N. F., Novais, R. F., Comerford, N. B., Costa, L. M., Neves, J. C. L., \& Alvarez, V. V. H. (1998). Phosphorus diffusive flux as affected by phosphate source and incubation time. Soil Sci. Soc. Am. J., 62(4), 1057-1061. https://doi.org/10.2136/sssaj1998.03615995006200040029x 
Vitousek, P. M., Porder, S., Houlton, B. Z., \& Chadwick, O. A. (2010). Terrestrial phosphorus limitation: Mechanisms, implications, and nitrogen-phosphorus interactions. Ecological Applications, 20(2), 5-15. https://doi.org/10.1890/08-0127.1

Weeks Jr., J. J., \& Hettiarachchi, G. M. (2019). A Review of the Latest in Phosphorus Fertilizer Technology: Possibilities and Pragmatism. J. Environ. Qual., 48, 1300-1313. https://doi.org/10.2134/jeq2019.02.0067

Withers, P. J. A., Sylvester-Bradley, R., Jones, D. L., Healey, J. R., \& Talboys, P. J. (2014). Feed the crop not the soil: rethinking phosphorus management in the food chain. Environ. Sci. Technol., 48, 6523-6530. https://doi.org/10.1021/es501670j

Zanão, L. A., Arf, O., Reis Jr, R. A., \& Pereira, N. (2020). Phosphorus fertilization with enhanced efficiency in soybean and corn crops. Australian Journal of Crop Science, 14, 78-84. https://doi.org/10.21475/ajcs.20. 14.01.p1862

\section{Copyrights}

Copyright for this article is retained by the author(s), with first publication rights granted to the journal.

This is an open-access article distributed under the terms and conditions of the Creative Commons Attribution license (http://creativecommons.org/licenses/by/4.0/). 